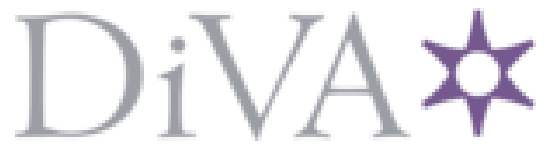

http://www.diva-portal.org

Preprint

This is the submitted version of a chapter published in The Harmonization and Protection of Trade Secrets in the EU: An Appraisal of the EU Directive.

Citation for the original published chapter:

Domeij, B. (2020)

The Trade Secret Directive and Employees

In: J. Schovsbo, T. Minseen \& T. Riis (ed.), The Harmonization and Protection of

Trade Secrets in the EU: An Appraisal of the EU Directive (pp. 149-170). Edward Elgar Publishing

N.B. When citing this work, cite the original published chapter.

Permanent link to this version:

http://urn.kb.se/resolve?urn=urn:nbn:se:uu:diva-417817 
This is a draft chapter. The final version is available in The Harmonization and Protection of Trade Secrets in the EU - An Appraisal of the EU Directive edited by Jens Schovsbo, Timo Minssen and Thomas Riis, published in 2020, Edward Elgar Publishing Ltd

https://doi.org/10.4337/9781788973342

The material cannot be used for any other purpose without further permission of the publisher, and is for private use only.

\section{The Trade Secret Directive and Employees}

Professor Bengt Domeij, Uppsala University, Sweden

\section{Introduction}

The tension between protection of trade secrets and employees is well known. Employees leaving for competitors necessarily have knowledge about the former employer's technical and administrative processes, colleagues' skills together with customers' identities and their contracts. Employees naturally desire to be able to move freely between employers bringing with them all knowledge, information and capacities, while employers understand that important commercial and technical information is possibly lost together with a departing employee. Any increased opportunities for employees to utilize trade secrets will push earnings to employees in the form of increased salaries, but also generally reduce market prices for products and services due to new or expanding competitors. Employers will suffer from, in addition to increased salaries and more competition, specific costs flowing from increased staff turnover such as the need for recruiting activity and replacement training. A general increase in the value of information in the economy combined with a trend of heightened employee mobility has accentuated the divergent interests. It is hardly surprising that litigation by companies against former employees is sometimes described as the most significant implication of the law on trade secrets. ${ }^{1}$

The new EU Trade Secret Directive has some provisions directly or at least primarily concerned with departing employees. This chapter aims to present and analyse what those provisions are and how they regulate labour mobility. In addition to the text of the Directive, case law on employees and trade secrets, from Sweden, Germany and UK will be discussed. The provisions in the Directive that will be analysed are (1) the distinction made in Preamble 14 between trade secrets and employee's skills and experiences; (2) the provision in Article 1, paragraph 3, stating that nothing in this Directive shall be understood to offer any ground for restricting the mobility of employees; (3) the provision on unlawful acquisition of trade secrets in Article 4, paragraph 2; and (4) finally how the employee's situation with regard to trade secrets is affected under the Directive by the end of the employment relationship, i.e. the period after employment.

The Directive is exclusively on civil law. ${ }^{2}$ Some national laws in EU member states will also have criminal sanctions for departing employees acquiring, using and disclosing trade secrets. There are further rules affecting trade secrets and labour mobility. The duty of fidelity during the employment

\footnotetext{
${ }^{1}$ M. Kolasa, Trade Secrets and Employee Mobility p. 1 (2018).

2 Directive Article 6, paragraph 1: “M ember States shall provide for the measures, procedures and remedies necessary to ensure the availability of civil redress against the unlawful acquisition, use and disclosure of trade secrets."
} 
is an important concern when employees prepare for later competition during the employment. The duty will restrict a range of preparatory act that employees otherwise might perform. The duty of fidelity may restrict e.g. a registration of a new company, preparation of business documents including a webpage, meetings with potential colleagues or customers, negotiations of a bank loan or meetings with investors. Duty of fidelity is regulated in national labour law and will not be touched upon in this chapter. Very important for labour mobility are any provisions in the individual employment contract concerning non-competition. National laws in Europe will continue to govern the extent to which such provisions are valid. The Directive states in Preamble 13 that it is not intended to affect the possibility of concluding non-competition agreements between employers and employees, in accordance with applicable law. Finally, it is significant in the context but will not be discussed in this chapter, that effects from departing employees can be mitigated by converting trade secrets into patent applications or financial incentive schemes in which a significant part of the wage is deferred and will be lost if the employee terminates the employment.

\section{Employee's skills and experiences}

The reach of the Directive is determined by Article 2(1), i.e. the definition of trade secrets. Information must be secret, of commercial value and the lawful holder must have taken reasonable steps under the circumstances to maintain its secrecy. The homogenous definition is to ensure a sufficient and consistent level of civil redress against misappropriate of trade secrets (Recital 10 of the Directive). Preamble 14 of the Directive provides some additional colour on the concept of trade secrets:

... The definition of trade secret excludes trivial information and the experience and skills gained by employees in the normal course of their employment, and also excludes information which is generally known among, or is readily accessible to, persons within the circles that normally deal with the kind of information in question.

Trivial information is excluded from the concept, which is presumably operational by the requirement of commercial value. M ore difficult to understand is how Article 2 of the Directive, implements the distinction in the Preamble between trade secrets, on the one hand, and experiences and skills gained by employees in the normal course of their employment, on the other. Can a departing employee, in addition to the criteria in Article 2 of the Directive, claim that the information in suit is not a trade secret because it is his or her experiences and skills gained in the normal course of the employment? The Articles are, of course, the operative parts of the Directive and the reference in the Preamble to employee skills and experiences must presumably be an elucidation of one of the criteria in Article 2. Say a pricing model - it is likely to be kept secret, be of commercial value, and the employer will probably also have taken reasonable steps to maintain its confidentiality - but is the knowledge concerning pricing not also the experience and skills gained by the employees in the normal course of employment? Would it then not be a trade secret? The question seems current and practical, yet difficult.

In implementing the Directive the Swedish government opted to provide explicitly in Section 2, paragraph 2 of the new Act on Trade Secrets (SFS 2018:558) that skills and experiences gained by an employee in the normal course of employment are not to be considered trade secrets. The provision is in addition to the criteria of secret, commercial value and reasonable measures to maintain secrecy. The Swedish government held that information anyone with adequate education could practice is a trade secrets belonging to the employer. However, if the information is connected to the individual in such a way that it cannot be easily transferred to another, it should be seen as information with personal character not belonging to the employer, i.e. employee skills and 
experiences. The Swedish Government continued by explaining that if the results from a certain technical procedure is primarily dependent on the instruction in the sense that the procedure usefully can be performed by more or less anyone in the field who carefully abide by the instructions, the instructions amount to trade secrets. But if a successful result of a procedure depends more on the personal skills and experiences by the person practicing the procedure, it is not protected under the Act. Finally, the Swedish government held that knowledge of market conditions learnt by employees in purchasing and sales activities should normally be seen as personal skills or knowledge and therefore do not belong to the employer. ${ }^{3}$

The distinction between, on the one hand, trade secrets and, on the other, employee skills and experiences, is perceived in Sweden and perhaps some other EU countries, to depend on how easily the information or skills, can be transferred between individuals. Trade secrets are easily transferred. This entails that trade secrets are more closely associated with the employer than with the individual employee. A trade secret can be told to new employees and will be characteristic of the employer as long as the information is kept secret from outsiders. Sweden is though, as far as I know, alone in explicitly providing in national law the distinction in Preamble 14 between trade secrets and employee's skills and experiences.

Alternatively, a distinction between trade secrets and skills of an employee is derived from the term "information" in Article 2. Kolasa argues that tacit knowledge is not a trade secret due to its inseparability from the person of the employee. ${ }^{4}$ Employee skills and experiences according to Preamble 14 are therefore not "information" as stated in Article 2 of the Directive. This is probably the answer to the relationship between the distinction made in Preamble 14 and Article 2 in the Directive. The TRIPS agreement also lends some support because employee skills constitute knowledge rather than information and for that reason are not deemed to be trade secrets. ${ }^{5}$ Information is a requirement in Section 2 of the Swedish Act on trade secrets. Thus, it appears to have been unnecessary for the new Swedish Act explicitly to exclude employee skills and experiences from the definition of trade secrets. It follows from the requirement of "information".

To summarize, the intention in the Directive is reasonably clear. Employee skills and experiences are distinct from trade secrets. Skills and experiences are not "information" under Article 2 of the Directive and therefore need not be assessed according to the further criteria in Article 2: secret, commercial value and reasonable measures to maintain secrecy.

The practical question is, of course, how to distinguish between protected information/trade secrets and employee skills and experiences. This is clearly very difficult or even impossible. It has even been coined the Theory of Inseparability. ${ }^{6}$ That said, at the extremes trade secrets and personal skills are probably quite easy to separate. ${ }^{7}$ In a delivery company the capacity to drive a lorry or ride a bike are obviously employee skills, while a lodger registering suitable routes to individual customers is most likely a trade secret because any driver with can use them. In practice, though, much information/knowledge in a company fall in between. Almost all professional tasks require some mix of easily transferable trade secrets and difficult-to-transfer skills and experiences. It seems to follow that only in extreme cases of claims to trade secrets the exception for employees' skills and

\footnotetext{
${ }^{3}$ Preparatory works to the new Swedish Trade Secrets Act, Swedish Governmental Proposal 2017/ 18:200 p. 35.

${ }^{4}$ M. Kolasa, Trade Secrets and Employee M obility p. 77 (2018).

${ }^{5}$ P. Wiebe Art. 39 paragraph 7 in J. Busche, P.-T. Stoll, A. Wiebe, TRIPs. Internationales und europäisches Recht des geistigen Eigentums Kommentar (2013).

${ }^{6}$ M. Kolasa, Trade Secrets and Employee Mobility p. 94 (2018),

${ }^{7}$ A. Ohly, Der Geheimnisschutz im deutschen Recht: heutiger Stand und Perspektiven, GRUR 1/2014 p. 10.
} 
experiences will control the outcome. However, having a distinction between trade secrets and the employee's general skill and knowledge, may require in litigation a precise identification by the employer of the confidential information in suit, which in turn makes it possible to avoid extensive intrusion into the employee's freedom. ${ }^{8}$

A void of cases on the distinction between trade secrets, on one hand, and employee skills/ experiences, on the other, has perhaps a further explanation. In many disputes involving employees, the distinction is simply unnecessary. Usually employees may not during employment use, but for their employment, neither trade secrets nor professional skills. Furthermore, in many but not all countries (see discussion below), former employees may (after the end of the employment) use both personal skills and loyally acquired trade secrets (as long as no documents are taken or information intentionally memorized). Sweden is such a country, i.e. one that by and large use the end of the employment to determine employees' right to practice both trade secrets and skills. The distinction between trade secrets and employee skills existed in Swedish law before the Directive was implemented, but had hardly ever been applied in case law. It was unnecessary because almost nothing followed from it. A former employee could, and still can, after the end of the employment in Sweden in almost all cases use honestly acquired trade secrets (see below for a detailed discussion). ${ }^{9}$ Employee are of course also free to use personal skills and experiences after the end of the employment. While during employment neither trade secrets nor skills or experiences, can be used for any purpose that damaged the interests of the employer. The distinction between trade secrets and employees' skills was consequently of little practical relevance. Countries with this set-up rarely need to distinguish between trade secrets and skills and will have limited case law on the issue. This is a further reason why it was probably unnecessary for the Swedish Government to legislate the distinction between trade secrets and employee skills in the Act. It might give rise to more legal questions than meaningful distinctions.

The conclusions from this portion of the chapter are that the drafters of the EU Directive on trade secrets made distinction between trade secrets and employee's skills/experiences. This is explicit in Preamble 14 and operable by the term "information" in Article 2. The distinction between, on the one hand, employee's skills and experiences, and on the other, trade secrets, is however conceptually difficult. The primary function may be that employers are in litigation compelled to individualize the pieces of information they claim. Furthermore, the distinction is unlikely to matter much if ex-employees are free to use trade secrets acquired in a loyal manner, i.e. by performance of the employee's duties. During employment neither skills nor trade secrets may be used in a way damaging the employer. After the employment, the distinction that matters is if the information has been acquired by performing employee duties, not whether it amounts to trade secrets or skills/ experiences.

\section{Directive is not to restrict mobility}

Article 1 of the Directive has the heading Subject matter and scope, in which paragraph 3 provides that:

\footnotetext{
${ }^{8}$ M. Kolasa, Trade Secrets and Employee M obility p. 57 (2018), referring to several UK sources inter alia Herbert M orris Ltd v Saxelby [1916] 1 AC 688 (HL) 699, 703 (Lord Atkinson); Gurry on Breach of Confidence: The Protection of Confidential Information paragraph 5.74 (2nd edn, 2012).

${ }^{9}$ Section 7, paragraph 2 of the The Swedish Act on Trade Secrets, and the preparatory works to said Act, Swedish Governmental Proposal 2017/18:200 p. 62.
} 
3. Nothing in this Directive shall be understood to offer any ground for restricting the mobility of employees. In particular, in relation to the exercise of such mobility, this Directive shall not offer any ground for:

(a) limiting employees' use of information that does not constitute a trade secret as defined in point (1) of Article 2;

(b) limiting employees' use of experience and skills honestly acquired in the normal course of their employment;

(c) imposing any additional restrictions on employees in their employment contracts other than restrictions imposed in accordance with Union or national law.

Article 1(3) is explicitly concerned with employees and limits the applicability of the Directive (its subject matter and scope). Subparagraph 3(a) provides that the Directive does not cover information not constituting trade secrets. Furthermore, subparagraph 3(b) provides that the Directive shall not offer any ground for limiting employees' mobility by limiting the use of experience and skills honestly acquired in the normal course of their employment. Interestingly, 3(b) on skills and experiences was cut down in size in the drafting of the Directive.

The original Commission proposal did not have a provision excluding application in certain cases. When, however, the proposal reached the European Parliament Committee on Legal Affairs, JURI, the question of employees and trade secrets was addressed. The European Parliament proposed that information, knowledge, experiences and skills honestly acquired in the normal course of a previous employment (not just skills and experience, as in the end-product) was to be unaffected by the Directive.

Draft European Parliament Legislative Resolution, 22 June 2015, Article 1, paragraph $2 \mathrm{~d}$ : This Directive shall not affect ... the use of information, knowledge, experience and skills honestly acquired by employees in the normal course of their previous employment, or in some other contractual relationship, which are not covered by the definition of a trade secret as provided for in point (1) of Article 2. ${ }^{10}$

The text proposed by the European Parliament might have entailed that all information honestly acquired/learnt in the normal course of an employment would be excluded from the Directive and therefore would be free to use after the employment. That probably proved controversial. Allowing former employees to use all honestly acquired trade secrets seems to contradict the legal situation in some member states. In the UK, in Faccenda Chicken v Fowler, [1986] 1 All ER 617, in the context of information used and acquired by an employee, the Court of Appeal drew a distinction between three categories of information: 1. trivial/easily accessible information that can be freely used; 2 . information that, although must be treated as confidential, once learned becomes an employee's own and can be used after employment ends; and 3. information that is so confidential it is considered a "trade secret" and cannot be used after employment ends (theoretically for an indefinite period).

\footnotetext{
${ }^{10}$ DRAFT EUROPEAN PARLIAM ENT LEGISLATIVE RESOLUTION, 22 June 2015, on the proposal for a directive of the European Parliament and of the Council on the protection of undisclosed know-how and business information (trade secrets) against their unlawful acquisition, use and disclosure (COM (2013)0813 - C70431/2013 - 2013/0402(COD)). Available at http:// www.europarl.europa.eu/sides/getDoc.do?pubRef=//EP//TEXT+REPORT+A8-2015-0199+0+DOC+XM L+V0//EN.
} 
UK Court of Appeal, Faccenda Chicken Ltd v Fowler ([1987] Ch 117, [1986] 1 All ER 625): While the employee remains in the employment of the employer, the implied obligations impose a duty of good faith or fidelity on the employee. The extent of the duty of good faith will vary according to the nature of the contract. The duty of good faith will be broken if the employee makes or copies a list of the customers of the employer for use after his employment ends or deliberately memorises such a list, even though (except in special circumstances) there is no general restriction on an exemployee canvassing or doing business with customers of his former employer. (4) After the termination of employment, the implied obligations become more limited in scope. A former employee is not allowed to use or disclose information which is of a sufficiently high degree of confidentiality so as to amount to a trade secret. The obligation does not extend to all information obtained during his employment and in particular may not cover information which is only confidential in the sense that unauthorised disclosure of such information to a third party while the employment subsisted would be a breach of the duty of good faith. (5) In determining whether any item of information is protected by the implied term after termination of employment, all the circumstances would be taken into account and in particular the following factors would be considered: (a) The nature of the employment - If the employment is in a capacity where confidential material is habitually handled this may impose a high obligation of confidentiality because the employee could be expected to realise the confidential nature of the information. (b) The nature of the information itself - The information is only protected if it can properly be classified as a trade secret or material which is in all the circumstances of such a highly confidential nature as to require the same protection as a trade secret. (c) Whether the employer impressed on the employee the confidentiality of the information. The attitude of the employer towards the information provides evidence which may assist in determining whether or not the information can properly be regarded as a trade secret. (d) Whether the relevant information can be easily isolated from other information which the employee is free to use or disclose.

The proposal from the European Parliament that all information, knowledge, experiences and skills, honestly acquired by employees in the normal course of employment should be unaffected by the trade secrets holder's rights under the Directive, seems to diverge from this leading UK case. The European Parliament's proposal probably also diverged from German civil law on ex-employees, see discussion below. Considering the situation in UK and Germany it was probably only to be expected that the amendment proposed by the European Parliament, did not survive.

In the final Directive, "information" and "knowledge" were deleted from Article 1.3(b) and only the terms "experience and skills" maintained. Consequently, the Directive does not offer any grounds for limiting employees' use of experience and skills honestly acquired in the normal course of their employment. Skills and experiences honestly acquired are, in the name of labour mobility, protected from the reach of trade secret law. However, this limitation of the subject matter and scope of the Directive then becomes confusing. The limitation in Article 1.3(b) does not seem to provide anything more than what follows from Article 1.3(a) ("this Directive shall not offer any ground for: (a) limiting employees' use of information that does not constitute a trade secret as defined in point (1) of Article 2;"). The "skills and experience" mentioned in Article 1.3(b) are not trade secrets under Article 2. Skills and experiences is not information, as discussed above, which in turn entails that Article 1.3(b) does not add anything to what follows from Article 1.3(a). It seems that Article 1.3(b) is 
redundant. Employee skills and experiences cannot be covered by the Directive already due to the definition of trade secrets.

\section{Unlawful acquisition of trade secrets by employees}

Article 4(2) of the Directive provides:

2. The acquisition of a trade secret without the consent of the trade secret holder shall be considered unlawful, whenever carried out by:

(a) unauthorised access to, appropriation of, or copying of any documents, objects, materials, substances or electronic files, lawfully under the control of the trade secret holder, containing the trade secret or from which the trade secret can be deduced;

(b) any other conduct which, under the circumstances, is considered contrary to honest commercial practices.

Subparagraph (a) entails that appropriation or copying of a trade secret without consent from the holder is unlawful. In situation of unlawful acquisitions access can be either authorized or unauthorized. In unauthorized access, the acquired trade secrets are not in work documents of the employee. The meaning of the term "unauthorized access" is derive from other sources, such as explicit or implicit contracts. ${ }^{11}$ Stepping outside employee work-duties makes the access unauthorized. Where access is authorized, the acts of appropriation/copying work documents by an employee may still amount to unlawful acquisition. In the absence of specific instructions, unlawful acquisition by employees will typically be the making of copies unrelated to work duties. After unauthorized/unlawful acquisition the trade secret holder lose factual control over the trade secrets. In the Swedish implementation of Article 4(2) unauthorised acquisitions was characterized as a situation where someone makes the trade secrets "theirs" in the sense of gaining independent control by unauthorised means. ${ }^{12}$

Anyone can commit unauthorised acquisition, but the provision is especially significant for employees because they usually have a high degree of unsupervised possession of trade secrets and therefor acquisition is relatively easy. It is common that a soon-to-depart employee, in anticipation of being excluded from customer lists, contracts, technical documentation, etc., acquire copies so that the files will continue to be available. Documents can be saved to a portable memory, printed on paper, e-mailed to a private account or even perhaps deliberately memorized. It is almost routine in some industries for employers to look for such activities. It may be a background program constantly running on the company IT-system alerting the IT-department to unusual activities and employers performing forensic IT-analyses of a workplace after an employee has departed for a competitor. If documents have been copied, printed or e-mailed to a private address, this is of course suspicious. However, employees routinely claim that the acts were done in performance of their work duties. Employees argue that the acts were an efficient way of working under the circumstances and not an attempt to gain independent control over the secrets. It may also be claimed that the information was need to safeguard the employee's bonus or other compensation. The employer may, on their part, be able to show that the acts, regardless of intent, violated an ITpolicy in force in the workplace. The question under Article 4(2) of the Directive will probably boil down to if violations of IT-policies, such as copying documents and bringing them home or using them outside a designated IT-equipment, are unlawful acquisitions under the Directive. M ore

\footnotetext{
${ }^{11}$ A. Ohly, Der Geheimnisschutz im deutschen Recht: heutiger Stand und Perspektiven, GRUR 1/2014 p. 6, reaching this conclusion in the context of German law.

${ }^{12}$ Swedish Governmental Proposal 2017/18:200 p. 39
} 
precisely, is intent to gain independent control a necessary part of unlawful acquisition? If so, per se forbidden acts under an IT-policy made to facilitate day-to-day work, would not qualify as unlawful acquisitions under the Directive. If intent is not necessary, per se unauthorized acquisitions performed in good faith, i.e. as part of work duties, amounts to unlawful acquisitions.

An alternative would be to hold that intent to have independent control is not necessary for unlawful acquisition, but damages would be adjusted in such cases. The Directive provides in Article 14 that M ember States shall ensure that an infringer who knew or ought to have known that he or she was engaging in unlawful acquisition, pay the trade secret holder damages appropriate to the actual prejudice suffered as a result of the unlawful acquisition. Subparagraph 2 of Article 14 of the Directive, states that Member States may limit the liability for damages of employees towards their employers for the unlawful acquisition, use or disclosure of a trade secret, where the employee acted without intent. This indicates that intent to gain independent control for the purpose of exterior uses of the trade secrets is not required for the act of acquisition. Provided the employee ought to have known that copying was not permitted it amount to unlawful acquisition. If there is an IT-policy in place prohibition employees from, say, using portable memories, copying may amount to unlawful acquisition even if done for work purposes. The damages should, however, be limited in such situations.

It is not certain, though, that any copying in breach of trade secret policies is unlawful acquisition. The Swedish government decided in implementing the directive that this is an open question. Only when it is clear that there was an intent by the employee to gain independent control, the employee ought to have understood that she violated the rules set by the employer. In implementing the Directive, the Swedish legislator decided that copying or other similar actions concerning documents containing trade secrets, in violation of an employer policy, in itself does not suffice for a finding of unlawful acquisition. It should often be necessary for the employer to prove a subjective intent on the part of the employee to acquire the trade secrets for him or herself. The Swedish legislator held that unauthorized copying done in an attempt to perform duties in the employment do not amount to unlawful acquisition:

An example of a situation where someone can be seen to have acquired a trade secret is when an employee without the permission of the employer brings a document, that the employee has lawful access to and that contains trade secrets, from the workplace to private dwellings with the purpose of making the documents the employee's own. Acquisitions of trade secrets can also happen when an employee copies documents and make the copies the employee's own. This may happen if electronic files are copied from devices of the lawful trade secrets owner to the employee's personal computer, or if the employee sends electronic files to a private e-mail account to which the employer has no access. ... Decisive in these situations is if the attacker performs some acts with the documents containing trade secrets, which the lawful holder has given the attacker access to, and the acts aim to make the documents with the trade secrets the property of the attacker. An employee copying documents containing trade secrets for the sole purpose of facilitating the employee's own work shall, on the contrary, not be seen to unlawfully acquire a trade secret under the Swedish Act. If the copies are brought from the workplace to the private dwellings this will not affect the determination if the purpose is no other than to work from home. This will be the case even if the copying is a violation of the employer's instructions. Employer's instructions and rules are, however, not inconsequential in determining if an attack on a trade secret has occurred. If the employer has explicitly 
prohibited that documents containing trade secrets are brought outside the employer's premises this often indicates an acquisition, if the employee keeps the documents in his or her home or in any other way have made them inaccessible to the employer. This may indicate that the employee has intended to make the documents the employee's property, especially if the documents remain [with the employee] after the termination of the employment and the employee does not wish to acknowledge the access to them or lack an acceptable explanation for the possession of the documents. ${ }^{13}$

The statements in the preparatory works to the new Swedish Act are not completely clear, but it seems that a breach of an IT-policy is not normally enough for a finding of an unlawful acquisition. Sometimes the employee "ought not to" have known that the acts were actually forbidden. It is for the employer to prove an intention to take independent control of the information. Acquisition occur if there is an intent to permanently gain independent possession of the trade secrets, but there is a grey zone in which the true policy may have been more permissible. Deviating from an ITpolicy is insufficient for unlawful acquisition, if done for work-related purposes. If the employee refuses to return material that has been copied in an unauthorized fashion, unlawful acquisition is obviously proven. The evaluation of an unauthorized acquisition must, it seems, be done on a caseby-case basis, taking into account all the evidence, especially the intentions by the employee in performing the copying and the relationship between a written IT-policy and the actual situation in the work place.

The background was that Swedish trade unions had argued that claims of unauthorized acquisition could be used by employers to threaten departing employees that had in good faith performed their duties but violated an IT-policy. The government accepted that there needed to be some safeguards or qualifications to unlawful acquisitions. The threat was that after an unauthorized acquisition of trade secrets, an injunction is likely to be issued (Article 12 of the Directive). Economic damages will follow from use or disclosure of trade secrets, but it is unlikely that a mere unlawful acquisition by an employee can cause serious economic damage. Damages due to moral prejudice are available, though, according to Article 14 paragraph 2.

In summary, it is far from certain that the gloss put on unlawful acquisitions by the Swedish government is a correct implementation of the Directive. It is debatable whether an acquisition should require more than a breach of the employer's policy, i.e. also require an intended to gain permanent and independent control over the trade secrets. It seems doubtful to this author if unauthorised acquisition by employees under Article 4 can be limited such.

\section{Trade secrets after termination of employment}

The Directive has some provisions explicitly for employees. Article 1.3(b) providing that nothing in the Directive shall be limiting employees' use of experience and skills honestly acquired in the normal course of their employment has been discussed above. The Directive has nothing, though, to say about the relevance of the termination of an employment, which is a bit surprising at least from a Swedish perspective. Article 4.3 of the Directive, on unlawful use or disclosure, generally provides the following:

3. The use or disclosure of a trade secret shall be considered unlawful whenever carried out, without the consent of the trade secret holder, by a person who is found to meet any of the following conditions:

\footnotetext{
${ }^{13}$ Swedish Governmental Proposal 2017/18:200 p. 143.
} 
(a) having acquired the trade secret unlawfully;

(b) being in breach of a confidentiality agreement or any other duty not to disclose the trade secret;

(c) being in breach of a contractual or any other duty to limit the use of the trade secret.

Firstly, if an employee learns trade secrets in the course of an employment, the employee has acquired the trade secret lawfully and therefore subparagraph (a) is not applicable. Article 4.3(a) of the Directive is applicable when the employee has unlawfully copied documents and maintained them post-employment. Preparation during employment for later use is universally regarded as a breach of trade secret rules. ${ }^{14}$ Where an ex-employee has access to notes or records, even if the documents were made legitimately during the employment, and uses them in the interest of a new employer, civil liability arises. ${ }^{15}$ Documents unlawfully maintained after the employment are the typical cases of trade secret breach by employees.

There are Swedish cases where employers have had no smoking-gun in the form of ITforensic studies showing copying during employment, but purely from behaviour post-employment have been able to prove that the former employee must have had access to copied documents. In the Swedish Labour court ruling AD 2013 no 24, a former head of sales at a factoring company had left and started working for a competing company. The Court held that the legal test was if there had been some abuse of loyalty during the employment, which there was no direct evidence of. It was also deemed possible that a head of sales could remember the 70 or so customers that had been contacted by him shortly after starting in the new position. Since the customers were in principle possible to remember, the fact that the contacted customers had nothing in common except being customers of the former employer was not evidence enough of an abuse of loyalty during employment. However, the employer could also show that his former head of sales had made the sales calls in an order directly corresponding to the customer list of the former employer. This was found to prove that the customer list had somehow been taken and used and therefore that trade secret protection had been infringed by the former employee.

Secondly, some, probably many, employment contracts have post-employment obligations concerning confidentiality and/or a duty to limit use of trade secrets learnt during the employment. With such contractual provisions in force, employees will be in breach of Article 4(3) b or c if the trade secrets are disclosed or used post-employment, unless of course the confidentiality or non-use contractual provision is unconscionable and invalid under national law. This far, the application of Article 4.3 in the Directive for employees is reasonably clear.

The third and particularly difficult situation, is where trade secrets have been loyally learnt in the course of an employment and then subsequently used or disclosed at another firm. Are trade secrets acquired in this manner, free to use post-employment or have they, under Article 4(3) b or c, been acquired under an implicit contract limiting their subsequent use or disclosure? How is a silent employment contract to be understood? Are trade secrets shared with employees solely for the purpose of the employment and that therefore there is a duty under Article 4(3) not to disclose or use trade secrets post-employment? This is the problem of trade secrets unintentionally pulsating in

${ }^{14}$ M. Kolasa, Trade Secrets and Employee M obility p. 155 (2018).

${ }^{15}$ W. van Caenegem. Trade Secrets and Intellectual Property p. 185 (2014). 
the brain of departing employees. The trade secrets can obviously not be returned and since there is no explicit contractual provision, it will amount to an issue of a possibly implied duty of confidentiality and non-use. As hinted at above, Swedish law takes the view that loyally acquired trade secrets can in all but exceptional circumstances be freely used by former employees.

In the Swedish Labour Court case AD 2003 no 61, the employee before terminating the employment had been involved in negotiations with potential customers. After the end of the employment he contacted the same customers and managed to convince some of them to enter into agreements with the new employer. The Labour Court found that there was no breach of rules on trade secrets when the information about the negotiations had been used by the employee for the benefit of the new employer. The employee had learnt about the potential deals by loyally performing his earlier duties.

It seems that the Directive does not address the question of former employees use or disclosure of a previous employer's trade secrets when the secrets have been acquired lawfully. At the time when the Directive was a proposal, Aplin raised this question and commented that it was terribly unclear whether the issue of ex-employees would be a matter for national law or a matter for EU-law:

[I]t can be argued that the position on employees and ex-employees will remain a matter of national law. This is because art. 3(3) [which later became art. 4(3) in the final Directive] refers to persons who are in breach of confidentiality agreements or other duties not to disclose a trade secret, or who are in breach of a contractual or any other duty to limit the use of the trade secret. It could be argued that the default position is for contract law to remain within the realm of national law, so that particularly with respect to contractual agreements and duties, national legal principles designed to protect former employees ... would still operate to determine whether particular contractual restraints are enforceable or not.... Probably the main argument in favour of employee and ex-employee liability being a matter of EU law is to avoid Member States adopting divergent interpretations and the consequent impact of such divergences on the mobility of employees within the EU. ${ }^{16}$

The final Directive is not clearer than the Proposal in terms of any duty imposed on ex-employees to respect trade secrets. Most commentators, though, believe that an implied duty for ex-employees not to use trade secrets loyally learned in the previous employment, must be derived from national law and is not in the Directive. ${ }^{17}$ Kolasa argues that contractual and implied contractual duties have not been harmonized under the Directive and the Directive simply does not contain sufficient guidance for a uniform understanding regarding post-employment duties. ${ }^{18}$ In the New German Act on Trade Secrets implementing the EU Directive, there are no provisions on ex-employees, something that the M ax-Planck-Institut für Innovation and Wettbewerb much regrets. The Institute states that the Directive does not address this issue despite its enormous importance and the Institute would have liked the national German legislator to regulate the issue in German law in order to enhance legal certainty in face of conflicting case law. ${ }^{19}$

\footnotetext{
${ }^{16}$ T. Aplin, A Critical Evaluation of the Proposed EU Trade Secrets Directive, Issue 4 Intellectual Property Quarterly 2014 p. 257 (270-271).

${ }_{17}$ M. Kolasa, Trade Secrets and Employee Mobility p. 153 and 156 (2018).

${ }^{18}$ M. Kolasa, Trade Secrets and Employee M obility p. 156 (2018).

${ }^{19} \mathrm{M}$ ax-Planck-Institut für Innovation and Wettbewerb, Stellungnahme zum Referentenentwurf eines Gesetzes zur Umsetzung der Richtlinie (EU) 2016/943 zum Schutz von Geschäftsgeheimnissen vor rechtswidrigem
} 
It is a considerable lacuna in the European protection of trade secrets that the default rule for former employees does not seem to be addressed in the Directive. Departing employees are perhaps the most significant source of loss of trade secret protection. It will also affect free mobility of labour in the internal market. But it seems that any obligations for former employees not to use or disclose trade secrets must continue to be derived from national rules in the state where the employment was habitually performed. UK, Germany and Sweden will briefly be compared in this respect.

The above discussed and cited UK case of Faccenda Chicken Ltd v Fowler, [1986] 1 All ER 617, suggests that trade secrets learned on the job may under certain circumstances be protected postemployment. Trade secrets were distinguished from mere confidential information in the period after employment. German civil law ${ }^{20}$ concerning ex-employees allows an employee freedom to use in principle all he or she has learnt in performing work duties. Exceptional additional facts may, however, lead a German court to hold that what the ex-employees did nonetheless amount to unfair competition or wrongful conduct. The conduct by an ex-employee giving rise to exceptional circumstances in German civil law can be exemplified by the Industrieböden-case where the information was the core trade secrets of the former employer and the departed employee had held a very well-paid position, had contributed nothing to the creation of the secrets, and his term of employment had been short. Although the broader principle requires freedom of an ex-employee to further his career with everything he previously has learnt, the BGH held that the use or exploitation of the trade secrets in this case was not required for the purpose. It was determined that the duty of loyalty extended beyond the period of employment. ${ }^{21}$

Erwerb sowie rechtswidriger Nutzung und Offenlegung vom 17. April 2018: "20. Den Erlass eines Stammgesetzes zum Schutz von Geschäftsgeheimnissen hätte der Gesetzgeber zum Anlass nehmen können, auch die Frage des Geschäftsgeheimnisschutzes im Arbeitsverhältnis - vor allem hinsichtlich nachvertraglicher Geheimhaltungsverpflichtungen ehemaliger M itarbeiter - zu regeln. Die Richtlinie adressiert diesen Themenkreis trotz seiner enormen Praxisrelevanz nicht, was seitens des M PI bereits in der seinerzeitigen Stellungnahme kritisiert worden war. In Deutschland ist diese Frage derzeit nicht gesetzlich geregelt, sodass inre Beantwortung bislang weitestgehend der Rechtsprechung überlassen war. Dass sich der

Referentenentwurf der Schließung dieser Lücke nicht annimmt, ist bedauerlich. Damit bleibt zum einen die Rechtsunsicherheit bestehen, die sich aus teilweise uneinheitlichen Entscheidungen des BGH und des BAG ergibt; zum anderen bleibt es beim allgemeinen Defizit an Rechtsklarheit." Available at

https://www.ip.mpg.de/fileadmin/ipmpg/content/stellungnahmen/Stellungnahme_zum_Referentenentwurf_ eines_Gesetzes_zur_Umsetzung_der_Richtlinie_EU__2016_943.pdf

${ }^{20}$ German law on trade secrets has been different from the law in most other European countries in that it is primarily based on criminal law, see A. Ohly, Der Geheimnisschutz im deutschen Recht: heutiger Stand und Perspektiven, GRUR 1/2014 p. 5.

21 "Industrieböden", Bundesgerichtshof (BGH) Urt. v. 21.12.1962, Az.: I ZR 47/61, available at https:// dejure.org/1954,396. The BGH held: „Denn auch bei Anwendung dieser Vorschrift könnte die Rechtswidrigkeit des Eingriffs in den Gewerbebetrieb nicht schon mit der Auswertung des Geheimnisses ohne weiteres als gegeben angesehen werden; es bedürfte vielmehr auch in diesem Rahmen einer sorgfältigen Abwägung aller Umstände, insbesondere der schutzwürdigen Interessen des Arbeitgebers gegen die des entlassenen Angestellten in derselben Weise wie bei der Anwendung der $\S \S 1$ UWG, 826 BGB (hierzu vgl. RGZ 166, 193, 199); das gleiche gilt für die Frage, in welchem Restumfange die erörterte vertragliche Treuepflicht des Angestellten nach seiner Entlassung fortdauert. Im Rahmen all dieser rechtlichen Gesichtspunkte geht daher ..., die Kardinalfrage dahin, wie weit man das Unternehmen mit einer geschützten Geheimsphäre umgeben darf, ohne dadurch die Angestellten des Unternehmens in der Benutzung der in ihm erlangten Kenntnisse, Fertigkeiten und Erfahrungen ungebührlich zu beeinträchtigen, wie sie zum Zwecke ihres Fortkommens und ihrer beruflichen Weiterbildung notwendig sind. ... [J] ] ded objektive Beurteiler müsse zugeben, daß es nach der Auflösung des Dienstverhältnisses Fälle des Geheimnisverrates gebe, gegen die sich das Rechtsgefühl auflehne; das seien die Fälle, in denen die Verwertung des Geheimnisses in keiner Weise 
In other German cases, it has been held that the possibility for former employees to use trade secrets in a new employment is broader than the opportunities to disclose the secrets to others or sell the same secrets to third parties.22 The paramount interest is in allowing an employee to use his or her skills fully for personal professional advancement, but it does not justify the same individual to trade in trade secrets. Another relevant factor in the assessment is the damage that the exemployee is able to inflict on the former employer. If the former employee is able to immediately and completely take over the employer's clients it indicates unfairness. ${ }^{23} \mathrm{An}$ implied duty of confidentiality seems in principle to be unlimited in time in German law, i.e. valid for as long as the information (trade secrets) remains secret. ${ }^{24}$ In summary, former employees are free to use trade secrets, but not in some specific situations or if they use documents except perhaps if the documents only reflect employee skills and experiences. ${ }^{25}$ Ohly characterizes the legal situation for ex-employees as vague and to some extent contradictory. ${ }^{26}$

The difference between the German and the UK position in the context of ex-employees is firstly that in Germany the starting principle is that an ex-employee is free to use all that he or she has learned loyally on the job. No formal attempt is made to distinguish between trade secrets and confidential information/know-how, where the latter is free to be used but the former is not which is the starting-point in the UK. However, in Germany, notwithstanding the freedom-in-principle, in particular cases it can be forbidden to use a trade secret post-employment even where it was obtained by loyally performing duties. ${ }^{27}$ Any limitation on the use of information post-employment is made by reference to all the circumstances in which the information was obtained and the circumstances in which it is to be used. ${ }^{28}$ The nature of the trade secret will in Germany play a role in this context, but not in terms of whether it is no more than know-how, but rather as how important it is to the firm, and also, the level of the employee in the firm, and whether he or she has contributed to its elaboration. ${ }^{29}$ Thus, in both UK and Germany a broad weighing up of interests are made and it is not apt to result in any great clarity or predictability. ${ }^{30} \mathrm{~A}$ practically unquestioned principle is, though, that information obtained in a dishonest way may not be used by the former employee. One may perhaps also conclude that where the information is essential for the former employee to be able to continue professionally in the same technology or trade, the employee's interest in his or her professional advancement will mostly prevail. ${ }^{31}$

Any European protection for trade secrets post-employment does not amount to a prohibition on competition. The so called "inevitable disclosure" doctrine is not accepted. ${ }^{32}$ Ex-employees in possession of trade secrets can start working with a competitor but may have to refrain from using or disclosing certain information. This is not per se deemed impossible in the sense that a disclosure

durch ein berechtigtes Interesse des Arbeitnehmers an der Verwertung seiner Arbeitskraft zu rechtfertigen sei; lediglich eine einseitige dingliche Auffassung des Betriebsgeheimnisses sei abzulehnen."

22 Bundesarbeitsgericht NJW 1988 p. 1686-1687 Kundenlisten. See also M. Kolasa, Trade Secrets and Employee Mobility p. 100 (2018)

23 BGH GRUR 1964 p. 215 M ilchfahrer and M. Kolasa, Trade Secrets and Employee M obility p. 102 (2018).

24 M. Kolasa, Trade Secrets and Employee M obility p. 116 (2018).

${ }^{25}$ A. Ohly, Der Geheimnisschutz im deutschen Recht: heutiger Stand und Perspektiven, GRUR 1/2014 p. 5.

${ }^{26}$ A. Ohly, Der Geheimnisschutz im deutschen Recht: heutiger Stand und Perspektiven, GRUR 1/2014 p. 1 and 9.

${ }^{27}$ BGH, GRUR 1983 p. 179 Stapel-Automat and M. Kolasa, Trade Secrets and Employee M obility p. 95 (2018).

${ }^{28}$ A. Ohly, Der Geheimnisschutz im deutschen Recht: heutiger Stand und Perspektiven, GRUR 1/2014 p. 10.

29 M. Kolasa, Trade Secrets and Employee M obility p. 118 (2018).

${ }^{30}$ W. van Caenegem. Trade Secrets and Intellectual Property p. 187-188 (2014).

31 M. Kolasa, Trade Secrets and Employee M obility p. 117 (2018).

32 W. van Caenegem. Trade Secrets and Intellectual Property p. 206-207 (2014). 
would be inevitable. Any duty of confidentiality or non-use must not put the former employee in a worse position than if he or she had not known about the trade secrets in the first place. This will probably in practice often make it difficult for the former employer to prove that unlawful disclosure or use of trade secrets have occurred.

Use or disclosure of honestly acquired trade secrets after an employment was a particularly contentious issue in the Swedish implementation of the Directive. The question had been specifically regulated since 1990 in Section 7 paragraph 2 of the Swedish Act on Trade Secrets, which provided that trade secrets learned by an employee are, except for exceptional cases, lawful for an employee to use after the term of employment. The end of the employment fundamentally altered the responsibilities. Case law and the preparatory works to the provision held that as long as no documents were taken by the employee or other disloyal behaviour, trade secrets learnt in the course of an earlier employment may be practiced, unless the employee had been in a very senior position in the company or perhaps if the employee had chosen the position with the intention of learning trade secrets.

In implementing the Directive the Swedish Government held that the existing legal rule on former employees' duties could be maintained under the Directive and, furthermore, that this was desirable. It was held in the preparatory works to the new Swedish Trade Secret Act that the Directive does not impose any general prohibition regarding use of other's trade secrets, i.e. does not contain a freestanding confidentiality or non-use obligation on former employees. Thus, it was not deemed obligatory, under Article 4.3 (b) or (c), to implement a duty for former employees to protect trade secrets. It was a matter for national law. The Government also mentioned that the employee's duty of loyalty ended with the term of the employment. ${ }^{33}$ The Government pronounced that the well-functioning and long-standing legal rules that allow a former employee to use trade secrets loyally acquired in the course of an employment, but in exceptional cases, is based on a reasonable compromise between the interests of, on the one hand, labour mobility and, on the other, companies' interest in trade secrets. The rule was easy to apply in practice for parties and courts, which was deemed an important advantage. ${ }^{34}$

In a comparison, one may perhaps say that courts in Germany and UK have slightly different starting points but both stress, concerning lawfully acquired trade secrets that it is necessary to carefully weigh up all the competing interests and exceptionally this may favour the employer. Swedish courts perform less of this over-all weighing-up exercise. The Swedish legislator has in the implementation of the Directive reiterated its belief in the benefits of the approach that trade secrets learnt by loyally performing duties associated with an employment, results in a possibility to freely use acquired trade secrets post-employment, except in clearly circumscribed and exceptional sets of circumstances. The Swedish approach is perhaps at an extreme end of national rules for exemployees concerning loyally acquired trade secrets. The "loyalty throughout the employment"-test is very dominant and has, as recently emphasized by the Swedish Government, the important quality of easy application. Millions of individual employees in Europe must each year consider their situation when terminating an employment. The Swedish focus on that no documents are taken on departure will be intuitive and relatively easy to understand. In actual practice, though, Sweden may not have such a disparate approach after all. This is because the preponderance of litigation concerns situations where either unauthorized documentation was used by the employee or provisions in the employment contract provide an explicit duty not to use or disclose the former

\footnotetext{
${ }^{33}$ Swedish Governmental proposal 2017/1nd sometimes 8:200 p. 62.

${ }^{34}$ Swedish Governmental proposal 2017/18:200 p. 62.
} 
employer's trade secrets. German, UK and Swedish law agree that former employees are prevented from using trade secrets in these two situations (documents are used or reasonable contractual provisions have been agreed). It may be that for implied duties concerning trade secrets, UK law is slightly more in favour of the employer and Sweden more tilted in favour of the employee. Germany may be in the middle. Yet the majority of fact-patterns would undoubtedly lead to the same outcome in the three countries. To appreciate the similarities van Caenegem's summary of the common law approach is apt:

Certainly in the common law jurisdiction, the requirements that: the alleged trade secrets are properly particularized; the private nature of each individual item is established; the measures taken to defend them are proven; and legal obligations are made clear to the employee at the time, mean that it is not easy for an employer to prove that some information is not just free know-how. Often courts either openly or surreptitiously have recourse to a rule of thumb, which is of dubious doctrinal status but has been present in English law since Robb v. Green [[1895] 2 QB 315]: if the employee cannot be shown to have made a deliberate and surreptitious effort to acquire the information in recorded form, there is a good likelihood that he will be able to continue to use all he has learned. Be that as it may, inherently separating trade secrets from know-how is conceptually and practically difficult. ${ }^{35}$

If the employee did not disloyally record the information, it will apparently frequently be that a common law court finds that the ex-employee is allowed to use it in competition with his exemployer. This could have been pronounced about Swedish law too. The focus is everywhere on disloyal acts of preparation during employment. In case of loyal acquired trade secrets, UK, Germany and Sweden ultimately all apply multi-factor tests. The employee's interest in making full use of his or her knowledge and capabilities is deemed fundamental. It is also stressed that it matters if the former employee can perform his or her new duties without the trade secrets of the former employer. This entails asking if the trade secrets can easily be separated from skills and experiences possessed by the former employee. Related to this is the principle that an employee's individual use of trade secrets is more legitimate than disclosure to others or even sale to third parties. The former employer's interest in preventing loss of important trade secrets is, of course, the fundamental counter-weight. The economic value of the trade secrets will greatly factor into the determination and perhaps this is emphasized a bit more in UK cases on trade secrets/confidential information. The degree of seniority that the ex-employee held at the former employer will be significant in all three jurisdictions. The extent to which the employee personally elaborated the trade secrets may also be important, at least in Germany and Sweden. Multifactor tests of this nature are of course common in law, but it must be rare that an individual in a high stake situation have to balance so many factors of different nature and where the relative weight of each is almost completely undefined. It is not a happy situation.

A simplified implied rule for post-employment use of trade secrets would have many advantages. The main problem, though, with a simple "loyalty throughout the employment"-test, such as in Sweden, lies with particularly highly value trade secrets. When they are at stake, say a particular research result not deemed desirable to patent or perhaps information concerning on-going contract negotiations, the employee can probably perform his or her duties for a new employer without disclosing or using the specific information. The ease of not using the trade secrets obviously speaks for an implied obligation to refrain. Then again, if the trade secret is of such high

${ }^{35}$ W. van Caenegem. Trade Secrets and Intellectual Property p. 200 (2014). 
value it would seem reasonable to expect the employer to include a confidentiality and/or non-use provision in the employment contract. That would solve the problem for the employer, also under Swedish law. Then again, parties often overlook the need to enter into contracts. Maybe therefore the Swedish default rule should be slightly modified to take better account of situations with specific and high value trade secrets.

To conclude, the Directive has left it to national law to regulate an important issues in the field of trade secrets: implied responsibilities for former employees. It is not inconceivable, though, that in due course there will be a question to the CJEU concerning the existence of minimum duties for former employees in regard to honestly acquired trade secrets. For the time being any implied obligation will be derived from national law. UK, Germany and Sweden apply multi-factor tests with considerable uncertainty. Swedish law endeavours to simplify, as far as possible, by providing that a duty for former employees not to disclose or use trade secrets, is narrowly circumscribed and only occur in specific situations: when documents have been used/preparations performed during employment, for very senior employees or if the employment was entered into for the purpose of gaining access to trade secrets. The Swedish rule has proven to be relatively easy to apply, but has possible drawbacks in cases of particularly high value trade secrets that the employee can avoid using in a new position. In the inevitable trade-off between incentives to develop trade secrets and employee mobility, the Swedish rule seems to be relatively well functioning. That said, contracts can and do regularly modify the situation when employer needs arise.

\section{Summary and concluding remarks}

In this chapter the responsibilities under the Trade Secrets Directive for employees have been chartered. Employees' skills and experiences are to be distinguished from information under Article 2(1) of the Directive, and only the latter may constitute trade secrets. The distinction is seldom applied, but require employers to specifically identify what information employees may not use. The provision on unlawful acquisition of trade secrets in Article 4, paragraph 2 of the Directive is applicable whenever an employee copy or otherwise appropriate trade secrets with the intention of gaining independent control. Uncertainty remains in situations where there may have been an ITpolicy in place but the employee may have perform his or her duties in a different manner without an intention to gain independent control. The Swedish legislator has determined that copying information in a manner not permitted under the employer policy will not be enough to find an unlawful acquisition if there was no indication of an intent to gain independent control. Finally, the employee's situation with regard to an employer's trade secret after termination of the employment is not directly regulated in the Directive. Any obligation post-employment is to be derived from national law. The law of Sweden, Germany and UK have different approaches to former employees, but the multi-factor tests that they all use probably in the end lead to quite similar outcomes. The Swedish government, though, has recently reiterated its belief in the value of keeping the assessment simple and that only in exceptional circumstances - disloyal behaviour during employment, very senior positions or if the intent from the beginning was to acquire trade secrets place any implied duty on former employees to maintain trade secrets.

The new EU Trade Secret Directive has hardly entailed major changes for employees, at least not in Sweden. The balances between employers and employees previously struck by national law is still more or less in place. As long as the EU does not harmonize agreed or implied contracts concerning trade secrets and employees, together with the very important issue of permissible scope of noncompetition provisions, the area will remain predominantly one of national law. The importance of employees and trade secrets for the internal market and labour mobility would favour 
harmonization, but the difficulty of finding a clear and common policy probably makes this unfeasible in the near future. 